\title{
Antagonizing GnRH receptors: A temporary ADT salvage maneuver for prostate cancer patients experiencing PSA failure with GnRH agonist
}

\author{
Jehonathan Pinthus, MD \\ Department of Surgery/Urology, McMaster University, Hamilton, ON, Canada
}

Cite as: Can Urol Assoc J 2020;14(2):42. hitp://dx.doi.org/10.5489/cuaj.6391

See related article on page 36

$\mathrm{T}$ he treatment of hormone-sensitive metastatic prostate cancer is currently changing from primary androgendeprivation therapy (ADT) by means of gonadotropinreleasing hormone $(\mathrm{GnRH})$ agonists, antagonists, or rarely orchiectomy to the combination of ADT with docetaxelbased chemotherapy or androgen receptor-axis-targeted (ARAT) agents. ${ }^{1,2}$ Accordingly, the potential clinical value of switching from a single-agent GnRH agonist-based ADT to single-agent $\mathrm{GnRH}$ antagonist-based ADT is likely limited to patients receiving ADT for biochemical failure.

The message from the meta-analysis by Atchia et al in this issue of CUAJ is restricted by the small number of studies included, the high risk for publication bias, and the lack of testosterone data and short-term outcome, all of which are well-acknowledged by the authors. Nevertheless, this report and others ${ }^{3}$ suggest a signal for potential superior prostatespecific antigen (PSA) control by GnRH antagonists compared to agonists. Could it possibly be that apart from androgen deprivation, GnRH antagonists exert additional anti-tumoral effects? Accordingly, one can conceptualize that usage of $\mathrm{GnRH}$ antagonists blocks three different intra-tumoral signaling pathways: the androgen receptor signaling pathway (by means of androgen deprivation), the follicle-stimulating hormone (FSH) signaling pathway (by means of ligand suppression), and the potential blockade of $\mathrm{GnRH}$ receptors that are often expressed in prostate cancer cells.

Recently, an increasing amount of evidence indicates that human GnRH and its receptor exert important regulatory components in the regulation of some cancer cell functions, such as cell proliferation, in both hormone-dependent and -independent types of tumors. ${ }^{4} \mathrm{GnRH}$ receptors are expressed in prostate cancer cells, specifically in the most aggressive stage of the tumor (castration-resistant prostate cancer). ${ }^{5}$ Regardless of the common ADT properties of $\mathrm{GnRH}$ receptor agonists and antagonists, it is plausible that intra-tumoral GnRH receptor inhibition by $\mathrm{GnRH}$

antagonists can further lead to anti-tumoral effects, while its activation by $\mathrm{GnRH}$ receptor agonists would not; they may even activate mitogenic signals. More so, FSH receptors have been demonstrated in $70 \%$ of clinical prostate cancer samples. ${ }^{6}$ Work from the 1990 s suggests that FSH may have a stimulatory effect on prostate cancer cell growth. ${ }^{7}$

Could the near elimination of FSH by GnRH antagonists reduce its stimulatory activity in prostate cancer cells? Could intracellular blockade of intra-tumoral GnRH receptors provide additional tumor suppression? We are currently investigating these questions in specially designed knockout models, which will hopefully provide a pre-clinical biological rationale for this concept. Further clinical validation and correlation with biomarkers will be needed to refine the exact patient population and clinical scenario for which potential triple intra-tumoral signaling blockade is advantageous.

Competing interests: Dr. Pinthus has been a consultant for Ferring and Myovant.

\section{References}

1. Fizazi K, Tran N, Fein L, et al Abiraterone plus prednisone in metastatic, castration-sensitive prostate cancer. N Engl J Med 2017;377:352-60. htrps://doi.org/10.1056/NEJMoal704174

2. Davis ID, Martin AJ, Stockler MR, et al. Enzalutamide with standard first-line therapy in metastatic prostate cancer. N Engl J Med 2019;381:121-31. https://doi.org/10.1056/NEJMoal903835

3. Crawford ED, Tombal B, Miller K, et al. A phase 3 extension trial with a 1-arm crossover from leuprolide to degarelix: Comparison of gonadotropin-releasing hormone agonist and antagonist effect on prostate cancer. J Urol 2011;186:889-97. https://doi.org/10.1016/i.juro.2011.04.083

4. Aguilar-Rojas A, Pérez-Solis MA, Maya-Núñez $G$, et al The gonadotropin-releasing hormone system: Perspectives from reproduction to cancer. Int J Oncol 2016;48:861-6. https://doi.org/10.3892/ iijo.2016.3346

5. Moretti RM, Marelli MM, Taylor DM, et al. Gonadotropin-releasing hormone agonists sensitize, and resensitize, prostate cancer cells to docetaxel in a p53-dependent manner. PLoS One 2014;9:e93713. https://doi.org/10.1371/journal.pone.0093713

6. Mariani S, Salvatori L, Basciani S, et al Expression and cellular localization of follicle-stimulating hormone receptor in normal human prostate, benign prostatic hyperplasia, and prostate cancer. J Urol 2006;175:2072-7. hitps://doi.org/10.1016/S0022-5347(06)00273-4

7. Ben-Josef E, Yang SY, Ji TH, et al Hormone-refractory prostate cancer cells express functional folliclestimulating hormone receptor (FSHR). J Urol 1999;161:970-6. hitps://doi.org/10.1016/S0022$5347(01) 61831-7$

Correspondence: Dr. Jehonathan Pinthus, Department of Surgery/Urology, McMaster University, Hamilton, ON, Canada; pinthusj@HHSC.CA 